\title{
Spontaneous regression of infantile dural-based non-Langerhans cell histiocytosis after surgery: case report
}

\author{
Yohei Miyake, MD, ${ }^{1}$ Susumu Ito, MD, ${ }^{1}$ Mio Tanaka, MD, ${ }^{2}$ and Yukichi Tanaka, MD² \\ Departments of ${ }^{1}$ Neurosurgery and ${ }^{2}$ Pathology, Kanagawa Children's Medical Center, Yokohama, Kanagawa, Japan
}

The authors report the case of a large left occipital mass lesion in an 8-month-old boy who presented with seizure. Neuroimaging demonstrated an approximately $5-\mathrm{cm}$ extraaxial tumor, and the patient underwent partial resection. The tumor was strongly attached to the tentorium and falx. In the postoperative course the residual lesion regressed spontaneously, and after 5 years only a slight residual tumor remained along the tentorium. Histopathological examination of the tumor revealed non-Langerhans cell histiocytosis (non-LCH). However, the tumor was not diagnosed as juvenile xanthogranuloma (JXG) because it lacked Touton giant cells. Hence, the authors described this lesion as a fibroxanthogranuloma.

Most intracraniospinal non-LCHs have been reported as JXG; however, several cases of xanthomatous tumors with histopathological features resembling those of JXG have been described as fibrous xanthoma, xanthoma, fibroxanthoma, and xanthogranuloma. Among JXG and the xanthomatous tumors, a review of the literature revealed several cases of dural-based tumors; these dural-based tumors have had favorable courses, including the case described in this report. In addition, the patient in the present case experienced spontaneous regression of the residual tumor. The authors report this unique case and review the literature on isolated intracraniospinal non-LCHs, especially in cases of dural-based lesion.

http://thejns.org/doi/abs/10.3171/2014.10.PEDS14378

KEY WORDS non-Langerhans cell histiocytosis; dural-based lesion; spontaneous regression; infant; oncology

$\mathrm{I}$ SOLATED intracraniospinal non-Langerhans cell histiocytoses (non-LCHs) without cutaneous lesion are rare. $5,10,11,14,19$ The most frequently reported lesion in these cases is juvenile xanthogranuloma (JXG), with several cases reported as fibrous xanthoma, xanthoma, fibroxanthoma, and xanthogranuloma (XG). ${ }^{1-3,5-9,11-18,21-39,41-44}$ Most reported intracraniospinal non-LCHs have been pediatric cases, and histopathological investigations show that they are composed mainly of xanthomatous histiocytes. In addition, several cases of intracraniospinal nonLCHs presented with dural-based lesions. We present an 8-month-old boy with isolated non- $\mathrm{LCH}$ attached to the dura mater in the left occipital region. Interestingly, the residual tumor regressed without treatment after surgery. We report this unique case and review the literature on isolated intracraniospinal non-LCHs, especially in cases of dural-based lesion.

\section{Case Report}

History and Examination

An 8-month-old boy who had experienced seizures with loss of consciousness and cyanosis at the age of 5 and 7 months was admitted to our hospital due to convulsive status. His growth and development had been normal, including head circumference. He had no cutaneous lesions. Physical examination and chest radiographs showed no definite abnormality. Head CT scans demonstrated a mass lesion approximately $5 \mathrm{~cm}$ in diameter in the left occipital region. Portions of the lesion showed high radiographic attenuation, and there was strong medial and rim enhancement (Fig. 1). The cerebral parenchyma was compressed but surrounding edema was mild. Magnetic resonance imaging showed hyperintense areas in the medial portion and rim of the tumor on T1-weighted studies (Fig. 2A).

\footnotetext{
ABBREVIATIONS $\alpha$-SMA $=\alpha$-smooth muscle actin; EMA = epithelial membrane antigen; GFAP = glial fibrillary acidic protein; JXG = juvenile xanthogranuloma; LCA = leukocyte common antigen; $\mathrm{LCH}=$ Langerhans cell histiocytosis; NFP = neurofilament protein; $X G=$ xanthogranuloma. SUBMITTED July 23, 2014. ACCEPTED October 17, 2014. INCLUDE WHEN CITING Published online January 30, 2015; DOI: 10.3171/2014.10.PEDS14378.

DISCLOSURE The authors report no conflict of interest concerning the materials or methods used in this study or the findings specified in this paper.
} 

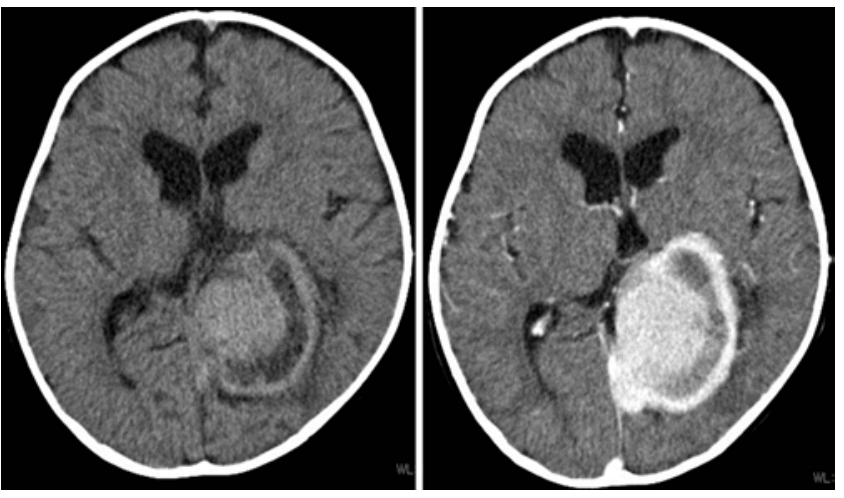

FIG. 1. Preoperative CT scans. Plain CT scan (left) demonstrating a mass lesion with an approximately $5-\mathrm{cm}$ diameter in the left occipital region. Enhanced head CT scan (right) showing a well-enhanced area in the medial portion and rim of the mass.

The mass demonstrated heterogeneous hypointensity on T2-weighted imaging (Fig. 2B). Diffusion-weighted imaging (Fig. 2C) showed hypointense areas, suggesting low cell density. The mass showed homogeneous enhancement contiguous with the dura mater, resembling meningioma (Fig. 2D and E).

\section{Operation}

The patient underwent tumor resection by left occipital craniotomy. The tumor was yellow colored, and strongly attached to the tentorium and falx; its consistency was very hard, and it was difficult to debulk even using an ultrasonic aspirator. Considering the surgical stress on the infant, we performed a partial (approximately 60\%) resection, and a staged operation was planned at that time.

\section{Histological Examination}

Macroscopically, the tumor was colored white-gray with areas of yellow, and appeared to arise from the cranial dura mater of the left occipital region.

On microscopic examination (Fig. 3), the tumor revealed abundant xanthomatous cells that had clear or slightly eosinophilic granular cytoplasm with thin fibrous stroma, aggregates of fairly uniform foamy histiocytes with scattered thin-walled blood vessels and occasional multinucleated giant cells (but not Touton giant cells), and dense fibrocollagenous tissue in which were embedded spindle-shaped cells occasionally arranged in a storiform pattern. No overt meningothelial whorls were seen. No significant mitotic activity or necrosis was found in the tumor. Scattered inflammatory cells composed predominantly of eosinophils were noted in the tumor, and some plasma cells and lymphocytes were also observed. Although an accumulation of foamy histiocytes was observed in the granulomatous lesion of the tumor, no cholesterol cleft, hemosiderin deposits, or multinucleated foreign body giant cells were noted.

On immunohistochemical examination (Fig. 4), CD68, HAM56, and CD163 were diffusely positive for xanthomatous cells and foamy histiocytes. These lipid-laden cells were focally positive for S100 protein. Vimentin was strongly and diffusely positive for spindle-shaped cells, but negative for CD1a, S100 protein, CD207 (Langerin),
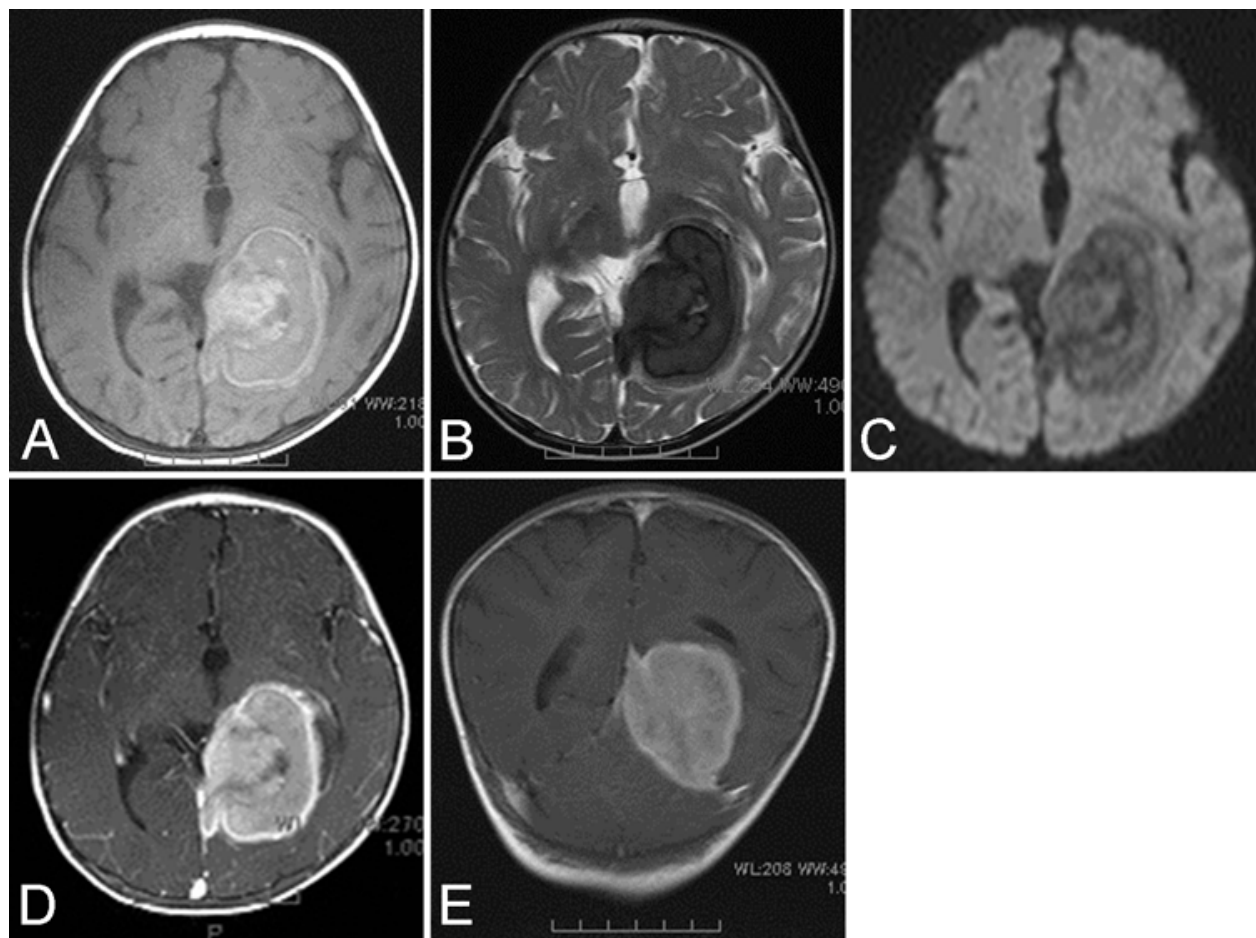

FIG. 2. Preoperative MRI studies. Axial T1-weighted MR image (A) demonstrating hyperintense areas in the medial portion and rim of the mass. The mass shows heterogeneous hypointensity on T2-weighted MR (B) and diffusion-weighted (C) images. Axial (D) and coronal (E) T1-weighted MR images obtained after contrast enhancement showing homogeneous enhancement contiguous with the dura mater. 


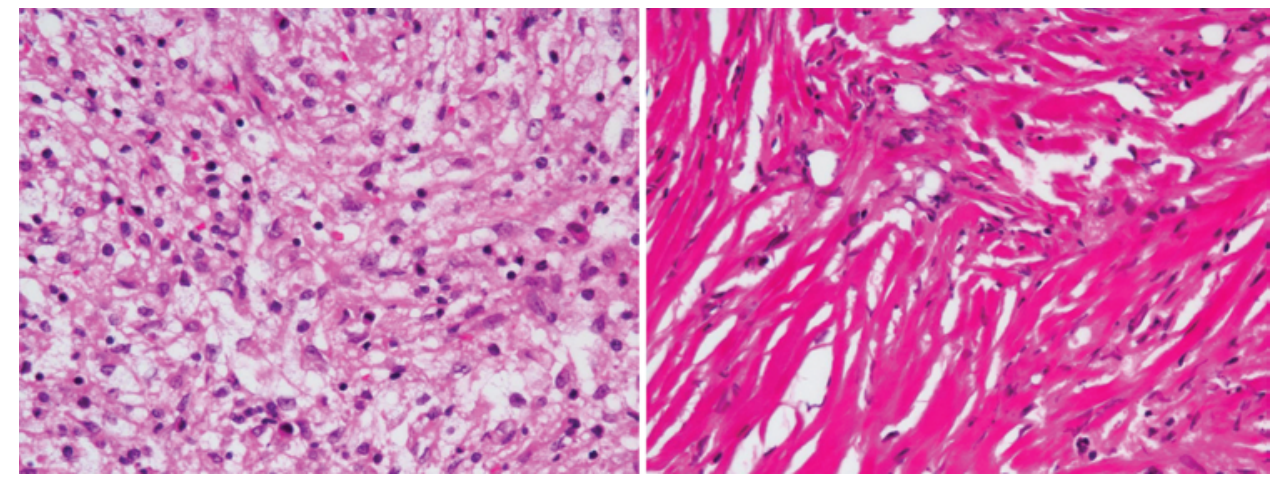

FIG. 3. Microscopic findings. The tumor reveals abundant xanthomatous cells with clear or slightly eosinophilic granular cytoplasm (left) and dense fibrocollagenous tissue in which are embedded spindle-shaped cells (right). $\mathrm{H} \& \mathrm{E}$, original magnification $\times 400$. Figure is available in color online only.

glial fibrillary acidic protein (GFAP), cytokeratin, epithelial membrane antigen (EMA), neurofilament protein (NFP), $\alpha$-smooth muscle actin ( $\alpha$-SMA), CD34, and leukocyte common antigen (LCA). The MIB-1 labeling index was approximately $1 \%-2 \%$.

Ultrastructurally, the tumor cells were relatively rich in cytoplastic organelles, but lacked cell-to-cell attachments and intercellular junctions. No overt Birbeck granules were detected.

Based on these histological findings, the lesion was diagnosed as non- $\mathrm{LCH}$, because it was positive for CD68, HAM56, and CD163, but negative for CD1a and CD207. The tumor did not present Touton giant cells, which are typical of JXG; hence, we described the lesion as a fibroxanthogranuloma. Based on the results of the immunohistological examination, the lesion is unlikely to be xantho- matous meningioma, solitary fibrous tumor, or pleomorphic xanthoastrocytoma.

\section{Postoperative Course}

Compared with a postoperative CT scan obtained at 1 week (Fig. 5A), the CT scan performed 3 months after surgery demonstrated spontaneous regression of the residual lesion (Fig. 5B). A follow-up CT scan performed approximately 1 year after surgery showed further spontaneous regression (Fig. 5C). The residual lesion continued to regress gradually, and as of approximately 5 years after surgery, only a slight residual lesion along the tentorium remained (Fig. 5D and E). The patient is presently achieving normal developmental milestones, is not receiving medications, and has experienced no seizures.

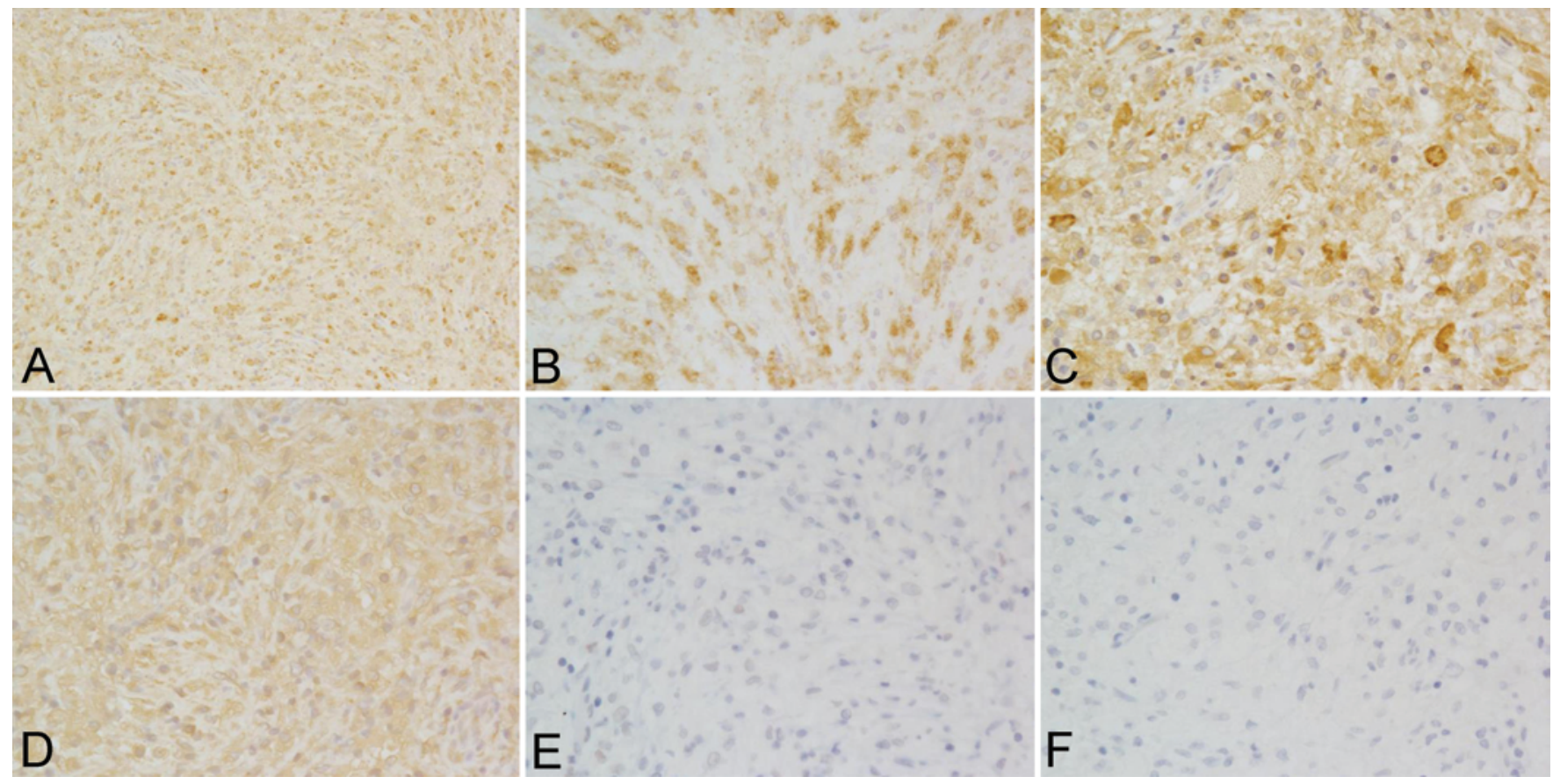

FIG. 4. Immunohistochemical findings. Staining for CD68 (A), HAM56 (B), and CD163 (C) demonstrates diffuse positivity for xanthomatous cells. Vimentin staining (D) shows strongly and diffusely positive results for the spindle-shaped cells, but negative results for CD1a (E) and CD207 (Langerin) (F). Original magnification $\times 400$. Figure is available in color online only. 

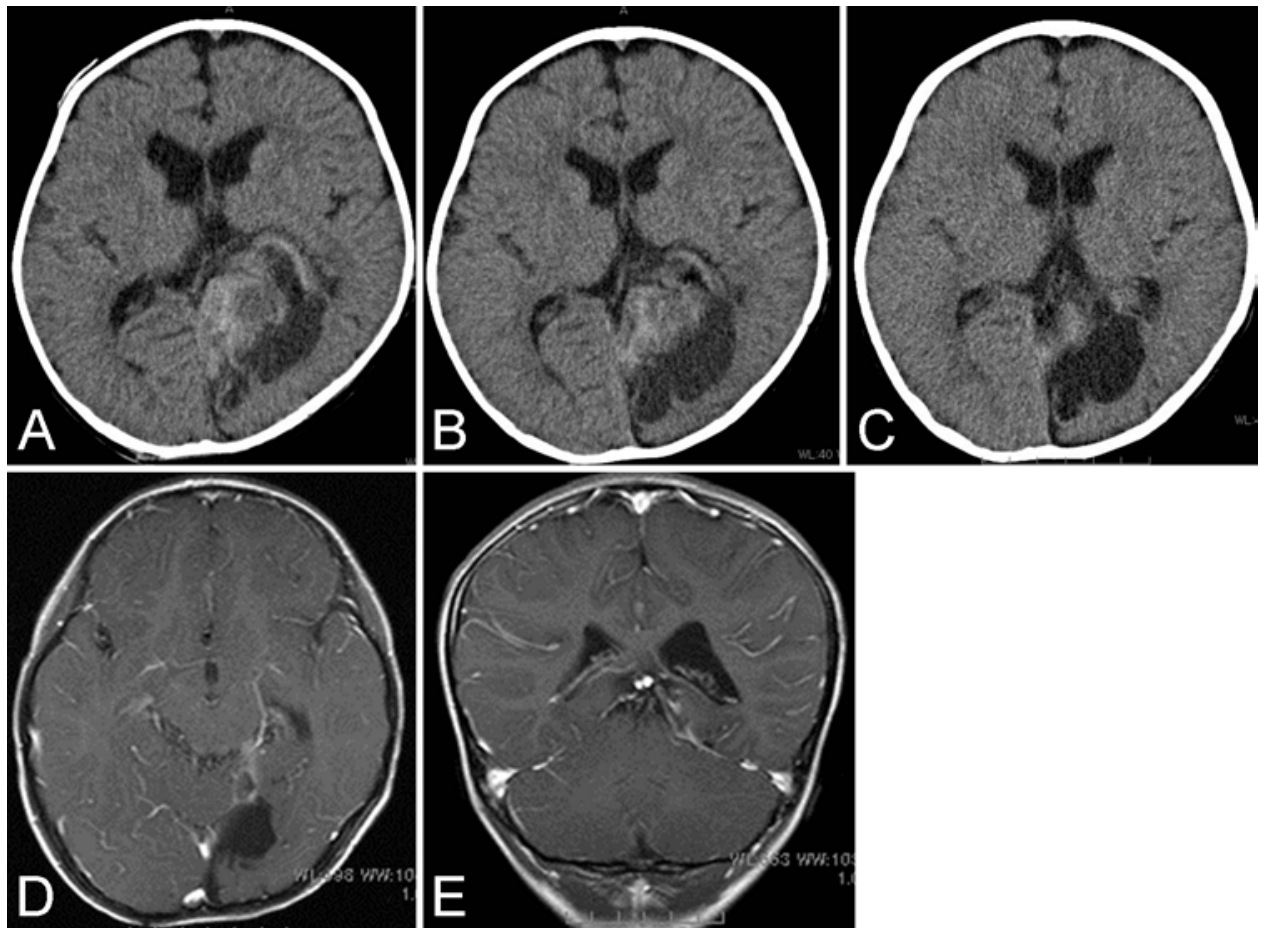

FIG. 5. Postoperative neuroimaging. Axial CT scans performed 1 week (A), 3 months (B), and 1 year (C) after surgery. The residual tumor shows spontaneous regression. Gadolinium-enhanced MRI studies performed 5 years after surgery (D and E) demonstrate only a slight residual lesion remaining along the tentorium.

\section{Discussion}

Cases of intracraniospinal non-LCH without cutaneous lesions are rare. ${ }^{5,10,11,14,19}$ The most common form of isolated non-LCH is JXG. ${ }^{3,5}$ To our knowledge, 29 cases of iso-

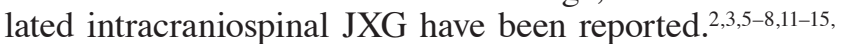
17,18,24,25,29,31-36,38,39,41-43 Histopathologically, JXG exhibits abundant lipid-laden histiocytes associated with mononuclear inflammatory infiltrates and a variable quantity of Touton giant cells. ${ }^{10,19}$ The immunohistochemical examination is typically positive for CD68, but negative for CD1a and S100 protein. ${ }^{8,10,11,19}$ Of the 29 cases, 17 were intracranial, 2,3,5,11,13-15,18,29,31,33,34,36,38,39,42 9 were intraspinal, $6,7,11,17,24,25,32$, 35,43 and 3 showed both intracranial and intraspinal lesions. ${ }^{8,12,41}$ Only one case was in an adult. ${ }^{17}$ Among the 29 cases, 22 followed a benign course, whereas 7 showed progression of the disease. . $^{8,22,29,31,33,39,41}$ These 7 cases occurred in Meckel's cave or presented with multiple lesions. Orsey et al. ${ }^{31}$ reported a JXG diffusely involving the CNS that subsequently underwent malignant transformation and dissemination to the peritoneum and bone marrow.

In addition to the 29 cases of JXG, 8 cases of isolated intracraniospinal xanthomatous tumors have been reported as fibrous xanthoma, xanthoma, and fibroxanthoma. ${ }^{1,9,21-23,27,28,44}$ Histopathological examination in these cases revealed a collection of foamy histiocytes with variable amounts of fibrous tissue. Four of these cases were immunohistochemically considered to be non-LCH, based on negative staining for CD1a or S100 protein. ${ }^{9,22,23,27}$ The pathological findings in the other cases also resembled those of JXG. 1,21,28,44 Most cases occurred in children and essentially followed favorable courses.
Another related lesion is XG; we found 4 cases of XG that were histopathologically similar to JXG. ${ }^{16,26,30,37}$ These cases were positive for CD68 and negative for CD1a, or showed Touton giant cells. The location was intracranial in 2 cases, ${ }^{16,30}$ and intraspinal in the other 2 cases. ${ }^{26,37}$ One case was in an infant, ${ }^{37}$ and the other 3 cases were in adults. ${ }^{16,26,37}$

Among the 42 cases of isolated intracraniospinal nonLCHs (reported as JXG, fibrous xanthoma, xanthoma, fibroxanthoma, and XG) including our case (Table 1), 18 cases (43\%) were dural-based lesions. ${ }^{1,2,5,9,11,16,21,22,25-28,30,32,35,37,38}$ Eleven of these 18 cases were intracranial ${ }^{1,2,5,9,16,21,27,28,30,38}$ and the other 7 were spinal. . $^{11,22,25,26,32,35,37}$ No cases showed recurrence during the follow-up period and essentially followed benign courses.

Interestingly, in our case, the residual tumor underwent spontaneous regression after surgery. Cutaneous JXGs are known to involute spontaneously. ${ }^{5,10}$ In addition, spontaneous resolution of extracutaneous JXG has been reported: these lesions occurred in the larynx, ${ }^{4,40}$ orbit, ${ }^{20}$ temporalpetrous bone,${ }^{10}$ and intraabdomen. ${ }^{10}$ Dehner suggested that JXG may have the capacity for self-healing or spontaneous regression. Of intracraniospinal cases, 1 case of regressive fibrous xanthoma has been reported. ${ }^{21}$ Non-LCHs may have the potential to regress spontaneously. Because all reported dural-based cases, including ours, have followed benign courses, they could be followed up without additional treatment after resection. However, close follow-up is mandatory in patients with lesions.

Among the non-LCHs that we reviewed, clinically similar tumors have been diagnosed as different pathological 


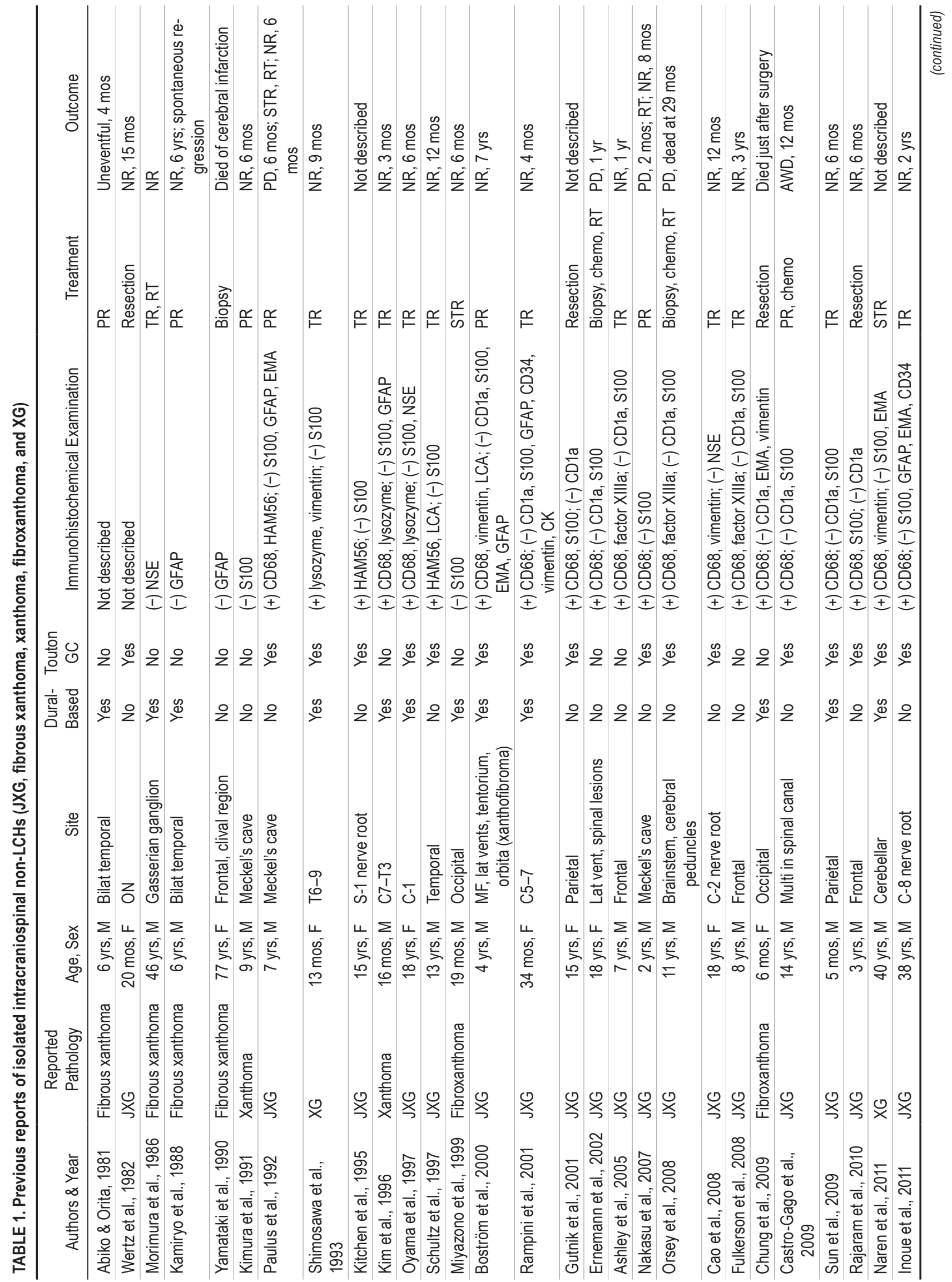




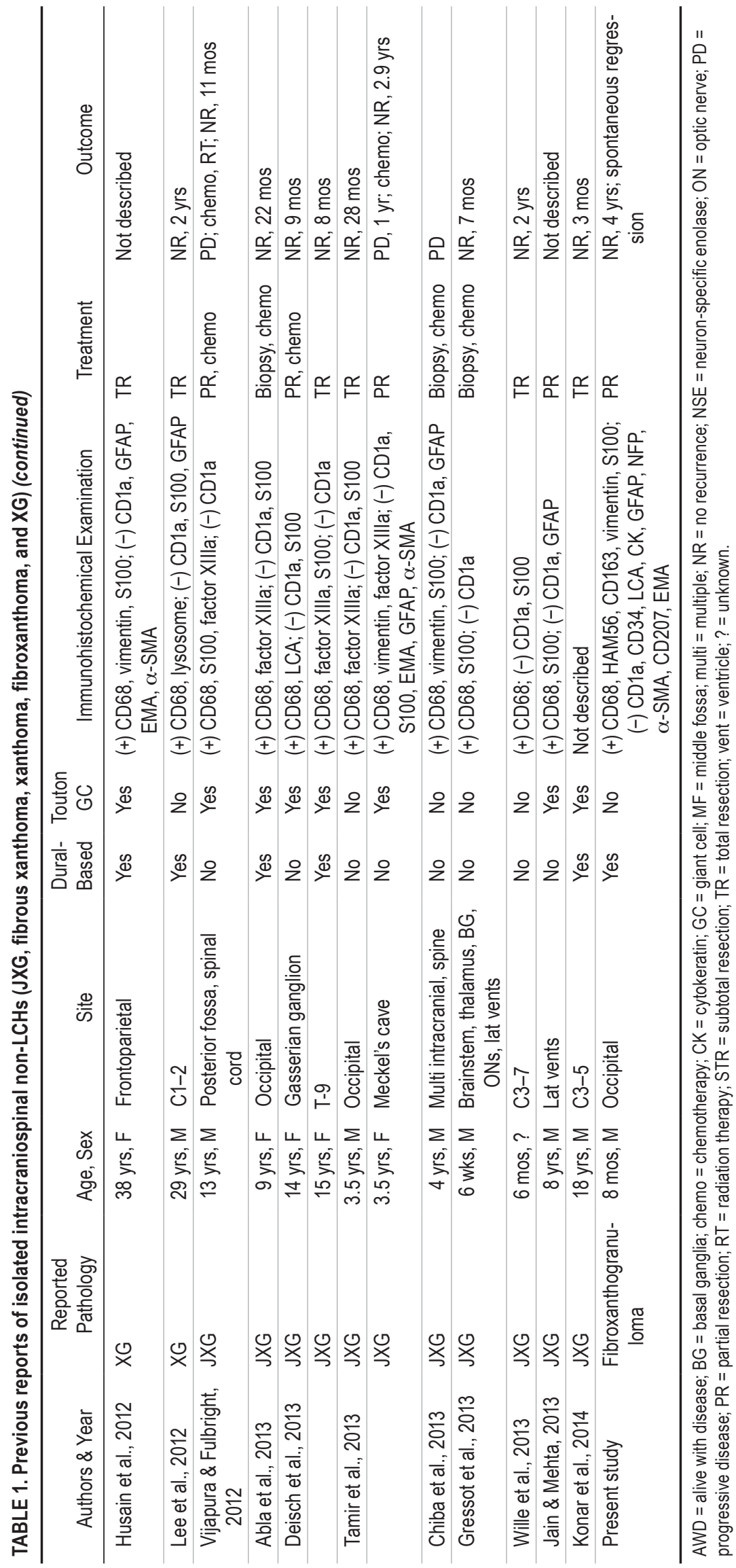


entities. Moreover, one pathological diagnosis, especially in JXG, has included both benign and malignant cases. Further investigations and the accumulation of more cases are needed to elucidate the pathogenesis of the non-LCHs.

\section{Acknowledgment}

Dr. Kiyoshi Gomi, Department of Pathology, Kanagawa Children's Medical Center, contributed greatly to this report. The authors dedicate this report to his memory.

\section{References}

1. Abiko S, Orita T: [A case of intracranial fibrous xanthoma (author's transl).] Neurol Med Chir (Tokyo) 21:979-984, 1981 (Jpn)

2. Abla O, Halliday W, Laughlin S, Weitzman S: Central nervous system juvenile xanthogranuloma after langerhans cell histiocytosis. Pediatr Blood Cancer 60:342-343, 2013

3. Ashley WW Jr, Narayan P, Park TS, Tu PH, Perry A, Leonard JR: Incidental pediatric intraparenchymal xanthogranuloma: case report and review of the literature. J Neurosurg 102 (3 Suppl):307-310, 2005

4. Benjamin B, Motbey J, Ivers C, Kan A: Benign juvenile xanthogranuloma of the larynx. Int J Pediatr Otorhinolaryngol 32:77-81, 1995

5. Boström J, Janssen G, Messing-Jünger M, Felsberg JU, Neuen-Jacob E, Engelbrecht V, et al: Multiple intracranial juvenile xanthogranulomas. Case report. J Neurosurg 93:335-341, 2000

6. Cao D, Ma J, Yang X, Xiao J: Solitary juvenile xanthogranuloma in the upper cervical spine: case report and review of the literatures. Eur Spine J 17 (Suppl 2):S318-S323, 2008

7. Castro-Gago M, Gómez-Lado C, Alvez F, Alonso A, Vieites B: Juvenile xanthogranuloma of the cauda equina. Pediatr Neurol 40:123-125, 2009

8. Chiba K, Aihara Y, Eguchi S, Tanaka M, Komori T, Nakazato Y, et al: Diagnostic and management difficulties in a case of multiple intracranial juvenile xanthogranuloma. Childs Nerv Syst 29:1039-1045, 2013

9. Chung IH, Lee YS, Myong NH, Lee MJ, Lee SK, Ko JH: Intracranial fibroxanthoma in an infant: a case report. Korean J Radiol 10:402-406, 2009

10. Dehner LP: Juvenile xanthogranulomas in the first two decades of life: a clinicopathologic study of 174 cases with cutaneous and extracutaneous manifestations. Am J Surg Pathol 27:579-593, 2003

11. Deisch JK, Patel R, Koral K, Cope-Yokoyama SD: Juvenile xanthogranulomas of the nervous system: a report of two cases and review of the literature. Neuropathology 33:3946, 2013

12. Ernemann U, Skalej M, Hermisson M, Platten M, Jaffe R, Voigt K: Primary cerebral non-Langerhans cell histiocytosis: MRI and differential diagnosis. Neuroradiology 44:759-763, 2002

13. Fulkerson DH, Luerssen TG, Hattab EM, Kim DL, Smith JL: Long-term follow-up of solitary intracerebral juvenile xanthogranuloma. Case report and review of the literature. Pediatr Neurosurg 44:480-485, 2008

14. Gressot LV, Patel AJ, Bollo RJ, Mohila CA, Jea A: Disseminated intracranial juvenile xanthogranulomatosis in a neonate without cutaneous lesions. J Neurosurg Pediatr 12:187-191, 2013

15. Gutnik H, Dolenc-Strazar Z, Popovic M: September 2000: 15 year old girl with intracranial lesion. Brain Pathol 11:123125,2001
16. Husain S, Alkhalidi HMS, Raddaoui E: A 38-year old woman with a dural based lesion. Brain Pathol 22:433-437, 2012

17. Inoue H, Seichi A, Yamamuro K, Kojima M, Kimura A, Hoshino Y: Dumbbell-type juvenile xanthogranuloma in the cervical spine of an adult. Eur Spine J 20 (Suppl 2):S343S347, 2011

18. Jain D, Mehta VS: Bilateral intraventricular mass in a child. Neuropathology 33:324-326, 2013

19. Janssen D, Harms D: Juvenile xanthogranuloma in childhood and adolescence: a clinicopathologic study of 129 patients from the Kiel Pediatric Tumor Registry. Am J Surg Pathol 29:21-28, 2005

20. Johnson TE, Alabiad C, Wei L, Davis JA: Extensive juvenile xanthogranuloma involving the orbit, sinuses, brain, and subtemporal fossa in a newborn. Ophthal Plast Reconstr Surg 26:133-134, 2010

21. Kamiryo T, Abiko S, Orita T, Aoki H, Watanabe Y, Hiraoka $\mathrm{K}$ : Bilateral intracranial fibrous xanthoma. Surg Neurol 29:27-31, 1988

22. Kim DS, Kim TS, Choi JU: Intradural extramedullary xanthoma of the spine: a rare lesion arising from the dura mater of the spine: case report. Neurosurgery 39:182-185, 1996

23. Kimura H, Oka K, Nakayama Y, Tomonaga M: Xanthoma in Meckel's cave. A case report. Surg Neurol 35:317-320, 1991

24. Kitchen ND, Davies MS, Taylor W: Juvenile xanthogranuloma of nerve root origin. Br J Neurosurg 9:233-237, 1995

25. Konar S, Pandey P, Yasha TC: Solitary juvenile xanthogranuloma in cervical spine: case report and review of the literature. Turk Neurosurg 24:102-107, 2014

26. Lee SJ, Jo DJ, Lee SH, Kim SM: Solitary xanthogranuloma of the upper cervical spine in a male adult. J Korean Neurosurg Soc 51:54-58, 2012

27. Miyazono M, Nishio S, Morioka T, Hamada Y, Fukui M, Yanai S: Fibroxanthoma arising from the cranial dura mater. Neurosurg Rev 22:215-218, 1999

28. Morimura T, Tani E, Yamaura I, Kochi N: Fibrous xanthoma in the gasserian ganglion: case report. Neurosurgery 19:139-141, 1986

29. Nakasu S, Tsuji A, Fuse I, Hirai H: Intracranial solitary juvenile xanthogranuloma successfully treated with stereotactic radiosurgery. J Neurooncol 84:99-102, 2007

30. Naren N, Sanjay K, Batuk D, Hanumant K, Alok S: Giant solitary symptomatic tentorial xanthogranuloma in an adult: a case report. Br J Neurosurg 25:744-746, 2011

31. Orsey A, Paessler M, Lange BJ, Nichols KE: Central nervous system juvenile xanthogranuloma with malignant transformation. Pediatr Blood Cancer 50:927-930, 2008

32. Oyama H, Ikeda K, Inoue S, Katsumata T, Murakami S, Doi A: [A case of intradural xanthogranuloma in the upper cervical spine.] No Shinkei Geka 25:745-748, 1997 (Jpn)

33. Paulus W, Kirchner T, Michaela M, Kühl J, Warmuth-Metz M, Sörensen N, et al: Histiocytic tumor of Meckel's cave. An intracranial equivalent of juvenile xanthogranuloma of the skin. Am J Surg Pathol 16:76-83, 1992

34. Rajaram S, Wharton SB, Shackley F, Raghavan A, Connolly DJ: Intracranial non-Langerhans cell histiocytosis presenting as an isolated intraparenchymal lesion. Pediatr Radiol 40 (Suppl 1):S145-S149, 2010

35. Rampini PM, Alimehmeti RH, Egidi MG, Zavanone ML, Bauer D, Fossali E, et al: Isolated cervical juvenile xanthogranuloma in childhood. Spine (Phila Pa 1976) 26:13921395, 2001

36. Schultz KD Jr, Petronio J, Narad C, Hunter SB: Solitary intracranial juvenile xanthogranuloma. Case report and review of the literature. Pediatr Neurosurg 26:315-321, 1997

37. Shimosawa S, Tohyama K, Shibayama M, Takeuchi H, Hirota T: Spinal xanthogranuloma in a child: case report. Surg Neurol 39:138-142, 1993 
38. Sun LP, Jin HM, Yang B, Wu XR: Intracranial solitary juvenile xanthogranuloma in an infant. World J Pediatr 5:71-73, 2009

39. Tamir I, Davir R, Fellig Y, Weintraub M, Constantini S, Spektor S: Solitary juvenile xanthogranuloma mimicking intracranial tumor in children. J Clin Neurosci 20:183-188, 2013

40. Thevasagayam MS, Ghosh S, O'Neill D, Panarese A, Bull PD: Isolated juvenile xanthogranuloma of the subglottis: case report. Head Neck 23:426-429, 2001

41. Vijapura CA, Fulbright JM: Use of radiation in treatment of central nervous system juvenile xanthogranulomatosis. Pediatr Hematol Oncol 29:440-445, 2012

42. Wertz FD, Zimmerman LE, McKeown CA, Croxatto JO, Whitmore PV, LaPiana FG: Juvenile xanthogranuloma of the optic nerve, disc, retina, and choroid. Ophthalmology 89:1331-1335, 1982

43. Wille DA, Bozinov O, Scheer I, Grotzer MA, Boltshauser E:
Isolated intraspinal juvenile xanthogranuloma in an infant presenting as acute paraplegia. Neuropediatrics 44:171-173, 2013

44. Yamataki A, Chiba Y, Tokoro K, Ide K, Yagishita S, Wakabayashi Y, et al: Multicentric intracranial fibrous xanthomacase report. Neurol Med Chir (Tokyo) 30:759-762, 1990

\section{Author Contributions}

Conception and design: Miyake. Acquisition of data: M Tanaka, Y Tanaka. Critically revising the article: Ito.

\section{Correspondence}

Yohei Miyake, Department of Neurosurgery, Kanagawa Children's Medical Center, 2-138-4 Mutsukawa, Minami-ku, Yokohama 232-8555, Japan. email: ymiyaken@gmail.com. 